\title{
First report of Botrytis cinerea on Cornelian cherry
}

\author{
Göksel Özer • Harun Bayraktar
}

Received: 18 July 2012 / Accepted: 7 February 2014 /Published online: 20 February 2014

(C) Australasian Plant Pathology Society Inc. 2014

\begin{abstract}
Botrytis blight of cornelian cherry (Cornus mas) was reported for the first time from Bolu, Turkey. The pathogen caused flower, leaf and twig blights. The disease was widely observed on cornelian cherry stands in Central and Yeniçağ districts of Bolu province. The fungus was identified as Botrytis cinerea based on mycological characteristics and molecular data.
\end{abstract}

Keywords Botrytis cinerea - Cornelian cherry · Cornus mas . Turkey

Cornelian cherry (Cornus mas) is a species of dogwood growing widely in different regions of Turkey. There are 977, 709 cornelian cherry trees with a production of approximately $12.427 \mathrm{t}$ per year in Turkey (Anonymous 2012). The fruits of cornelian cherry are used in the production of foods such as jams, marmalades, drink, syrups, and soups as well as consumed as fresh fruits. Also, it provides basic materials for medicinal purposes. Despite the widespread use of its fruits, little information is available about the diseases of cornelian cherry in Turkey.

Botrytis cinerea is a necrotrophic pathogen causing economically important diseases on many plants such as fruits, vegetables, nursery stocks, ornamental plants and orchard crops (Jarvis 1977; Elad et al. 2007). Botrytis disease causes death on flower parts, leaves, buds, shoots, seedlings and fruits (Ellis 1971). The pathogen is a common and serious disease of cornelian cherry and flowering Dogwood

G. Özer

Abant İzzet Baysal University, Bolu 14280, Turkey

H. Bayraktar $(\bowtie)$

Faculty of Agriculture, Department of Plant Protection, Ankara

University, Ankara 06110, Turkey

e-mail: harunbayraktar@hotmail.com
(Cornus florida) during wet spring weather in Italy (Garibaldi et al. 2009).

In May-June 2011, the disease was widely observed on stands in Central and Yeniçağ districts of Bolu province. The symptoms appeared on flower bracts as small, brown spots, that expanded and later become covered with a layer of graybrown mycelia and conidia. Infected flower parts fell on the leaves. Brown necrotic lesions and mycelial growth developed on the diseased leaves, causing affected leaves to roll and distort. Seriously affected twigs became completely dry and died (Fig. 1).

The diseased tissues were cut into $3 \mathrm{~mm}$ pieces and surface-sterilized by immersion in $2 \% \mathrm{NaOCl}$ for $1 \mathrm{~min}$. The cuttings were rinsed in distilled water, placed on potato dextrose agar (PDA) medium and incubated at $23{ }^{\circ} \mathrm{C}$ for 7 days. Isolates developed from the diseased tissues were sub-cultured on PDA medium and purified with single spore isolation. A total of 29 isolates were preserved on filter paper at $4{ }^{\circ} \mathrm{C}$. Morphological and molecular characterization studies were carried out in order to identify Botrytis cinerea.

Morphological identification was performed according to Ellis (1971) and measured the dimensions of 30 conidia and sclerotia from each isolate. In order to produce the conidia, isolates were grown in Petri dishes containing PDA medium as described above. To produce the sclerotia, isolates were kept in the dark at $8 \pm 1{ }^{\circ} \mathrm{C}$. Colonies of $B$. cinerea on PDA were colourless at first, with the mycelial growth becoming gray to brown 15 days later and conidia forming in cultures. Conidia were single-celled, ovoid to ellipsoid, colourless to pale brown, smooth and measured $6.8-10 \times 8.1-11.9 \mu \mathrm{m}$. Conidiophores were brown, slender and branched with enlarged apical cells bearing clusters of conidia. Most of the isolates produced black sclerotia on PDA medium. Sclerotia were round or irregular and ranged from 0.8 to $1.2 \times 0.9$ to $1.6 \mathrm{~mm}$ in size. 
Fig. 1 Symptoms caused by Botrytis cinerea on cornelian cherry (Cornus mas). a Plants showing Botrytis blight symptoms; b Entirely necrosed flower parts; c Leaf symptoms caused by Botrytis cinerea; $\mathbf{d}$ Twig blight of cornelian cherry

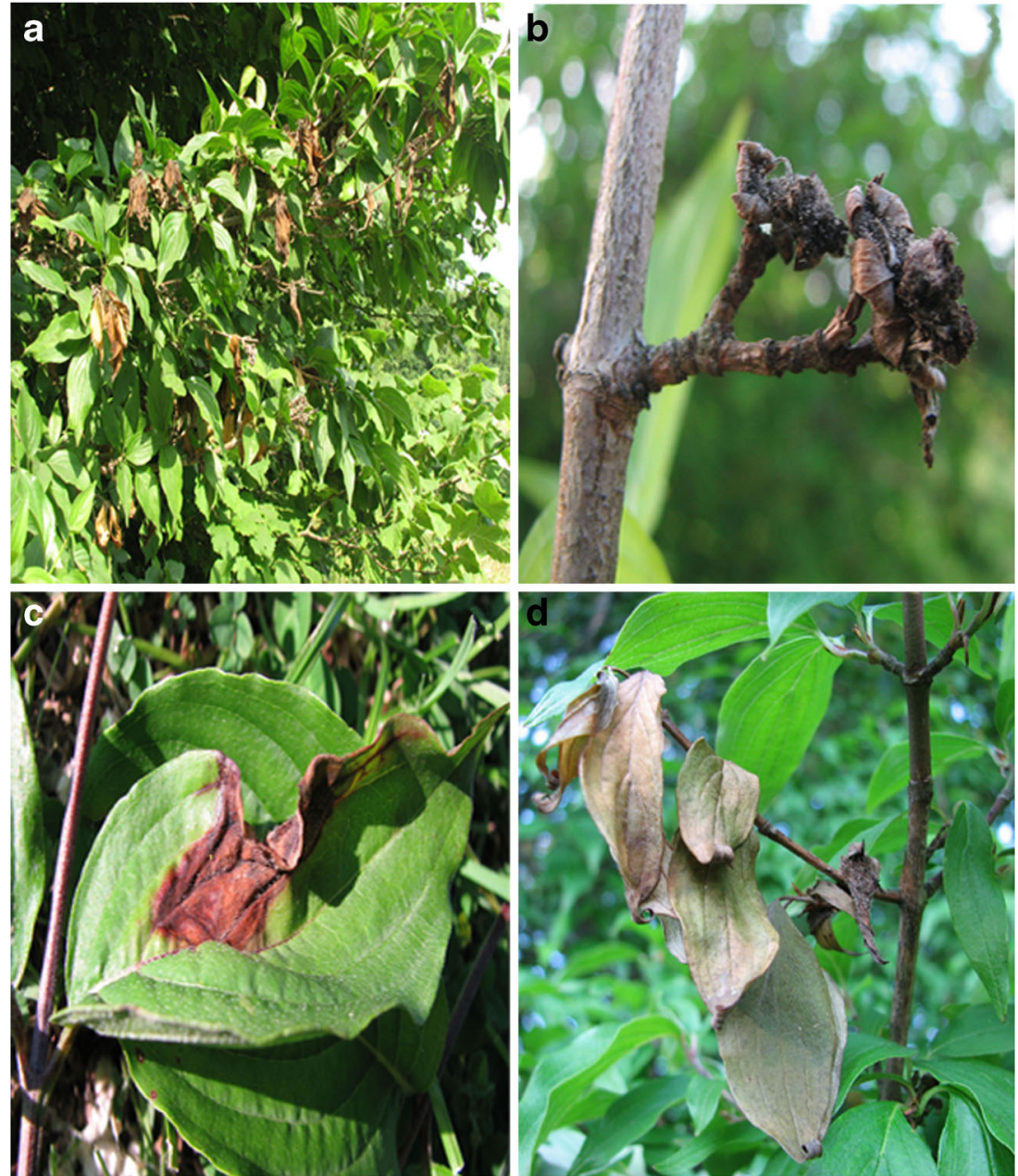

Ellis (1971) reported similar cultural and morphological characteristics for $B$. cinerea.

To confirm the identity of the causal fungus, single-spore isolates of $B$. cinerea were subjected to species-specific PCR assay using the primer pairs $\mathrm{C} 729+/-$ described by Rigotti et al. (2002). These specific primers permitted the amplification of a single DNA fragment of $0.7 \mathrm{~kb}$ in size. The complete ITS rDNA and Bc-hch gene of the representative fungal isolate were amplified and sequenced using the primers ITS1/4 and 262/520L, respectively (White et al. 1990; Fournier et al. 2005). The resulting sequences were deposited in GenBank under accession numbers KC595267, KF453971 and showed 99-100 \% sequence similarity with other ITS and Bc-hch sequences of B. cinerea in GenBank, respectively. Also, B. cinerea isolates were stored in $15 \%$ (v/v) glycerol in water at $-70{ }^{\circ} \mathrm{C}$ and deposited in the culture collection of the Department of Plant Pathology at the Agricultural Faculty, Ankara University (accession numbers: AÜZF 1013-1042).

The pathogenicity of $B$. cinerea isolates was tested by inoculating cornelian cherry leaves with one agar disc per leaf. The leaves collected from non-infected trees were surface-sterilized as above, placed on moistened filter papers in Petri dishes and inoculated with mycelial and conidial plugs $4 \mathrm{~mm}$ in diameter, from 7 day old cultures. Inoculated leaves were incubated for 7 days at $23{ }^{\circ} \mathrm{C}$ in a $12 \mathrm{~h}$ dark/light cycle. Control leaves were inoculated with a pathogen-free agar disc. Disease symptoms developed on the inoculated leaves within 3 days after inoculation. At the end of the 5th day, gray-brown mycelia and conidia growth were observed on affected areas. The causal pathogen was re-isolated from the lesions to confirm Koch's postulates. No disease symptoms were observed on the control leaves.

On the basis of morphological characteristics, pathogenicity testing on host plant, and molecular assays, the fungus was identified as $B$. cinerea. To our knowledge, this is the first report of Botrytis cinerea causing blight symptoms in cornelian cherry in Turkey. The economic importance of the pathogen appears to be limited because dry weather stops disease progression before serious damage occurs. 


\section{References}

Anonymous (2012) Turkish Statistical Institute http://www.tuik.gov.tr. Accessed 10 July 2012

Elad Y, Williamson B, Tudzynski P, Delen N (2007) Botrytis spp. and diseases they cause in agricultural systems. In: Elad Y, Williamson B, Tudzynski P, Delen N (eds) Botrytis: Biology, pathology and control. Kluwer, Dordrecht, pp 1-24

Ellis MB (1971) Dematiaceous hyphomycetes. Kew, Commonwealth Mycological Institute, p 608

Fournier E, Giraud T, Albertini C, Brygoo Y (2005) Partition of the Botrytis cinerea complex in France using multiple gene genealogies. Mycologia 97:1251-1267
Garibaldi A, Bertetti D, Gullino ML (2009) First report of Botrytis blight caused by Botrytis cinerea on flowering Dogwood (Cornus florida) in Italy. Plant Dis 93(5):549

Jarvis WR (1977) Botryotinia and Botrytis species: Taxonomy, Physiology and Pathogenicity. A guide to the Literature. Ottawa, Canada, Department of Agriculture, Monograph No 15

Rigotti S, Gindro K, Richter H, Viret O (2002) Characterization of molecular markers for specific and sensitive detection of Botrytis cinerea Pers.: Fr. in strawberry (Fragaria ananassa Duch.) using PCR. FEMS Microbiol Lett 209:169-174

White TJ, Bruns TD, Lee S, Taylor J (1990) Amplification and direct sequencing of fungal ribosomal RNA for phylogentics. In: Innis MA, Gelfland DH, Sninsky JJ, White TJ (eds) PCR Protocols: A guide to methods and applications. Academic, San Diego 